\title{
Deregulated free-for-all planning, new settlements and the spectre of abandoned building sites in Scotland's crisis-hit oil economy
}

\author{
WILLIAM WALTON
}

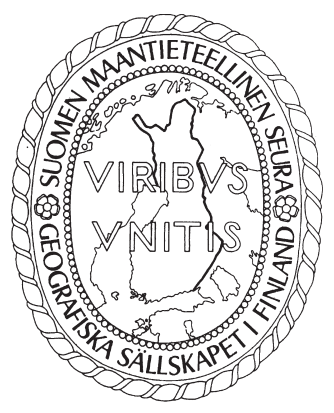

\begin{abstract}
Walton, W. (2018) Deregulated free-for-all planning, new settlements and the spectre of abandoned building sites in Scotland's crisis-hit oil economy. Fennia 196(1) 58-76. https://doi.org/10.11143/fennia.65626
\end{abstract}

$\mathbf{y}$ The creation of new settlements as a response to the accommodation of household growth was regarded by the Scottish Government from the 1980s to around 2008 as an option of the last resort. This position changed due to significant legislative and policy changes to the Scottish planning system which diluted restrictions on greenfield housing development and removed the right for public hearings into development plan objections in the belief that these procedures hindered economic growth. This paper outlines the evolution of planning policy for new settlements from the 1990s to the present and examines its impact upon proposals for such projects in north-east Scotland. It contends that the removal of the right to hearings into major development proposals is symptomatic of both the post-politics condition which seeks to promote neoliberal values by squeezing out dissenting voices and green light administrative law theory which vests important decisions over citizens' rights in the hands of unaccountable state bureaucrats. Finally it considers the implications of the current North Sea oil crisis for the development of three new settlements in the area.

Keywords: planning, development plan examinations, new settlements, Scotland, red light/green light, post politics

William Walton, School of Law, Northumbria University, CCE1, Newcastle-uponTyne, NE1 8ST, United Kingdom. E-mail: william.walton@northumbria.ac.uk

\section{Introduction}

Since the 1990s there has been a consensus across much of the UK that the state and the market have jointly failed to provide sufficient housing for those on medium to low incomes. The problems created by lack of affordability and the steep house price gradients between fast growing and lagging regions have led to rigidities in labour markets and consequential economic inefficiency. In Scotland, adopting the same supply side approach as advocated by Kate Barker in England and Wales (Barker 2004), the Scottish Government concluded that to materially reduce house prices there would be a need to increase dwelling output from around 25,000 per year to 35,000 per year by 2020 (Scottish Government 2007). This requirement for additional housing has cascaded down to the 32 local authorities who have responded through making considerably more land available in their strategic development plans (SDPs) and local development plans (LDPs). This task has been facilitated by the near contemporaneous programme of deregulatory planning reform. Signalled through the White Paper 'Modernising the Scottish Planning System' and implemented through the Planning etc (Scotland) Act 2006

URN:NBN:fi:tsv-oa65626

DOI: 10.11143/fennia.65626 (cc) BY (c) 2018 by the author. This open access article is licensed under a Creative Commons Attribution 4.0 International License. 
and numerous accompanying statutory instruments, this programme has sought to produce a simplified and more responsive land use management system capable of achieving greater social inclusion, stronger environmental protection and, above all, enhanced levels of development and economic growth (Peel \& Lloyd 2006).

These policy and legislative changes have led to several development plan allocations and planning approvals across Scotland for private new settlements, comprising anywhere from 500 to 5,000 or more houses, with some in train of construction. Although the concept of private sector-led new settlements is by no means new in Scotland, most previous proposals met with rejection following a process of scrutiny during which the public and other users of the planning system could closely evaluate their compatibility with national and local policy. Today, however, in sharp contrast to the 1980s and 1990s, developers have been able to secure approvals relatively easily through the new expedited 'light touch' development plan review procedures in which the scope for the public to make meaningful objections has been very heavily circumscribed.

This new light touch approach to development plan approval is part and parcel of the Scottish Government's desire to affect a so-called 'cultural change' to the planning system. Whilst not explicitly defined with any great clarity, this cultural change appears to amount to a belief in the need for the planning system to secure more development, more quickly consistent with the protection of critical natural capital. A core component within this strategy was the decision to significantly diminish the opportunity of those individuals and groups objecting to new development plan proposals to ventilate their views in public hearings and test the local authority's/developer's case. Explicitly, the change was motivated by a desire to make the system of development plan approval less adversarial and thus fairer to under resourced communities worn down by consultation fatigue. Implicitly, it was in large part motivated by a desire to sideline well organised vocal minorities ('stoppers') who were generally regarded as being unrepresentative of the wider community (the silent majority) which had a more accommodating and more pragmatic approach to new development and economic prosperity (Short et al. 1986).

The paper commences through examining the process of planning reform in Scotland, specifically in regard to the process of the examination of development plans, through the lens of post-politics theory and red light/green light administrative law theory. It then moves on to review the impact which deregulatory planning reforms in Scotland have had on the policy framework relevant to new settlement proposals from the 1990s to the present. The paper then reviews new settlement promotion in the Aberdeen area of north-east Scotland, first during the 1970s to 2008 when planning policy was more highly regulated, and then from 2009 to the present when the policy became more deregulated. Data for housing land supply and construction is sourced from local authority development plans and monitoring reports. This is supplemented by responses from interviews conducted with two former Members of Scottish Parliament (MSPs), a planning Reporter, a civil servant and four community councillors from Aberdeen/Aberdeenshire ${ }^{1}$. Finally, in the light of the current North Sea oil crisis the paper considers whether north-east Scotland is heading for a property crash caused through over-production.

\section{Post-politics and green light public law theory}

The desire to foreclose the opportunities for parties to express their dissent is consistent with two distinct yet overlapping theoretical stances; first, the post-politics condition as associated in urban planning in particular with Oosterlynck and Swyngedouw (2010), Counsell, Haughton and Allmendinger (2012), Allmendinger and Haughton (2012), MacLeod (2013), and Deas (2014) and, second, the 'red light/green light' administrative law theory as coined by Harlow and Rawlings (2009). Post-politics is a condition generally associated with an ostensibly shrinking, rather than an expanding, state in which neoliberal values of profit accumulation, economic growth and economic efficiency are hegemonic and taken as normal ${ }^{2}$. Land use planning is legitimate only to the extent that it helps create and sustain the conditions in which these values can best be achieved. To do this it helps to nurture a fake consensus in which the scope for expressions of dissensus, agonism and 'political' debate over alternative values by competing interests is highly limited. First order issues - such as the exploitation of land value and the pursuit of developer profit - are taken as being beyond the bounds of legitimate 
debate and thus not open for discussion and disagreement. Instead, public debate is essentially confined to second order matters such as where development should take place and what it should look like (although, here again, only as long as it does not prejudice the pursuit of first order principles).

Increasingly, planning decisions are made within a web of soft spaces in which technocratic experts working within policy networks comprising numerous public and quasi public bodies (such as local economic development agencies) are considered to offer the only legitimate viewpoints whilst those with dissenting voices are increasingly isolated, ignored and squeezed out (Haughton et al. 2013). Where such soft spaces are less evident, as in the more localised system of government that operates in Ireland (and arguably in rural Scotland) dissenting voices still invariably fail to be heard, being squeezed out by more established stakeholders such as large house builders and business representative organisations (Counsell et al. 2012). Within this post politics context, public hearings into development plan objections are only likely to be tolerated if their remit is sufficiently narrow as to preclude members of the public from questioning the fundamental assumptions governing such matters as development targets incorporated within higher order national policy frameworks and if they can be conducted expeditiously without resulting in significant changes likely to cause undue delay to plan preparation.

'Red light' theory has its intellectual roots in the doctrine of the rule of law associated with the $19^{\text {th }}$ and early $20^{\text {th }}$ century jurist A. V. Dicey (Dicey 1902). It contends that the primary function of the law is to curb any excesses by the Executive in the use of its powers in order to protect private property and private contractual rights. Although in the first instance it was no doubt hoped that a vigilant legislature would act as a check on the unbridled powers of the executive it was recognised that the primary safeguard would be provided by (red light) interventionist courts. However, the further expansion of the state in the early 20th century into areas such as education, housing and health and the adoption of Keynesian demand management post-1945 necessitated a move away from reliance solely upon fixed rules to the increasing use of statutory instruments, policy statements, best practice guides and circulars. The implementation of this 'quasi legislation' (Megarry 1944) or 'soft law' (Sossin \& Smith 2003) was largely policed through the exercise of discretionary judgment by local and state bureaucrats (Davies 1969). It is this more light touch approach at the far end of the regulatory spectrum (Ganz 1972) which Harlow and Rawlings (2009) characterise as 'green light'. But if discretionary powers were construed too widely by the Executive there would be the obvious risk of unjust outcomes arising from their inconsistent application from one bureaucrat to another, from one jurisdiction to another and from case to another. Consequently, most of the statutory codes - whether determining people's rights to build a home or to operate a taxi firm - incorporated some form of appeal system whereby an aggrieved party could have his case reconsidered by an inspector acting in a quasi judicial function. We might refer to this as an 'amber light' safeguard mechanism occupying an intermediary point along Ganz's regulatory spectrum.

Despite their arguably very different political-economy contexts, neoliberal post-politics and Keynesianism green light administrative law theory seem to be united in the belief that economic or governmental elites are best placed to make decisions on behalf of the ordinary citizenry in many dayto-day policy areas. Under the condition of post-politics policy and business elites - acting through the state - seek to deny the majority of citizens the opportunity to challenge higher order policies because they cannot be trusted for fear that this might result in the dismantlement of the underlying neo liberal orthodoxy of economic expansion. Similarly, under green light administrative law theory local and central state bureaucrats consider themselves to be best placed to make decisions to advance the general welfare of the wider population. The extent to which these theories explain the rationale for the changes introduced by the Scottish Government to the development plan examination process will become evident as the paper progresses.

\section{Planning reform in Scotland}

Following the devolution of most domestic powers from Westminster to Edinburgh in 1998 the Labour/Liberal Democrat coalition administration prioritised the reform of the Scottish planning system within its legislative agenda. Proceeding from the premise that the existing system was unduly 
complicated - indeed, almost dysfunctional - the administration set out to simplify and accelerate the processes of development plan preparation and planning application determination. It contended this would help increase public engagement and trust, and promote both greater social inclusion and sustainable economic growth. To affect this the Scottish Executive ${ }^{3}$ called upon all of those engaged in planning to become less entrenched in their views and - through what it called a 'cultural change' "...to reassert the collective project of land use planning and development..." (Peel \& Lloyd 2007, 490) - to focus on the delivery of new development in the appropriate locations through, inter alia, the faster preparation of development plans.

The problem of delay in plan making had become more acute following the introduction of the Planning \& Compensation (Scotland) Act 1991. Prior to that date the law held that the relevant decision maker (usually the local planning authority) had to have regard to the development plan and to any other 'material considerations' such as any shortage of development land when determining a planning application. After 1991, however, the law changed so that planning applications had to be determined in line with the development plan unless material considerations indicated otherwise. Because the post-1991 system considerably elevated the legal status of the development plan it became imperative for landowners and developers to try and ensure that the plan allocated their sites for profitable forms of development such as residential and retail uses. To do this these interests would need to be involved at every stage of the plan preparation process including at the public inquiry where they could participate either to object to the council's failure to include their site(s) for development or, possibly, to try and protect their development allocation being transferred to a rival operator claiming to have a more appropriate site.

The development plan framework in Scotland comprises a National Planning Framework (NPF) setting out national infrastructure priorities and, in the four city regions (Edinburgh; Glasgow; Dundee; and Aberdeen), an upper-tier SDP and, for all 32 lower-tier authorities (and two national parks), an LDP ${ }^{4}$. Housing numbers are set out in the SDPs in the four city regions and by the LDPs in the rural areas beyond. The SDPs identify the broad scale and location of development (e.g. 1,000 houses in town $\mathrm{X}$ ) across the jurisdiction, which are then translated into site specific proposals in the daughter LDP (e.g. 150 houses at site X). The first stage of plan preparation involves drafting a 'Main Issues Report' in which - consistent with a requirement to provide for a specified level of development (the quantum issue is not open for discussion) - the council identifies a range of potential sites for the public to consider and provide feedback to assist in the process of selecting the most appropriate (or the least objectionable). Two further versions of the SDP/LDP are produced, with the final one being submitted for formal scrutiny. Until 2007 the scrutiny of the upper-tier plan had always been performed by the Minister through consideration of written representations. In contrast, the scrutiny of the LDP had, prior to 2007, always included a public inquiry. On conclusion of the inquiry and consideration of written representations the Reporter would propose any recommended changes such as the deletion of a proposal - to the council which could accept or reject his advice (the Reporter's amendments became de facto binding from 2006 onward) ${ }^{5}$. Once the local plan had been adopted it would form the basis for the determination of planning applications.

Public inquiries are used in a variety of contexts within the UK's system of administrative justice (Wade \& Forsyth 2000). As previously stated, they can be viewed as an 'amber light' mechanism to curb against the possibility of the abuse of administrative discretion. They are routinely used to resolve objections into major projects, largely because the adversarial style is widely regarded as allowing for the competing evidence to be tested to best effect. But whilst public inquiries allow for greater transparency in the planning process they have nevertheless been subject to considerable criticism since their introduction in the 1970s. Lay people might find their highly formal, quasi judicial procedures intimidating and exclusionary, or the attitude of professionals as patronising and condescending (Rydin 1993). Objectors to a development proposal might be frustrated by rules preventing them from challenging the basis of the underlying policy (such as the assumptions underlying the calculations of housing need) (Cullingworth \& Nadin 2002). Some might conclude that inquiries are little more than ritualistic shams which provide no more than a superficial appearance of impartiality in order to confer legitimacy on a process which is intrinsically favourable to developers, landowners and the state (Tyme 1978). But others adopt a more positive approach to their use. For 
example, Owens and Cowell (2011) contend that public inquiries have opened up opportunities for conservation interests to challenge notions of sustainability and question the legitimacy of schemes such as roads and mineral workings.

There has been little research on the effectiveness of the oral presentation of a case at local plan inquiry, in particular for a local community group although that which there is suggests that it can use the mode materially to its advantage (Smith et al. 1986; Webster \& Lavers 1991). However, there is a good data base of statistics for Scotland, England and Wales as regards the comparative effectiveness of oral against written presentation of cases in appeals against refusal of planning permission. In England and Wales, appellants have a considerably greater chance of overturning decisions where a public inquiry is used as against a hearing or written representations. In Scotland, the position is more mixed although the small number of public inquiries typically held each year into planning appeals makes it more difficult to draw meaningful conclusions ${ }^{6}$.

The large numbers of objectors combined with the requirements for natural justice - permitting each party the opportunity to cross examine the evidence presented by opposing parties - meant that many local plan inquiries would sometimes run for 12 months or more ${ }^{7}$. Inevitably this contributed seriously to the problem of delay prompting questions over the efficacy of the system. Resolving the issue of plan delay was a critical aspect of the Scottish Executive's planning reform agenda. It argued a need to move away from public inquiries and adopt less formal, inquisitorial means of eliciting the public's opinion through roundtable discussions (Scottish Executive 2003a). These were contended to be in the best interests of overstretched communities whom - it was claimed - only had a very limited understanding of the complexities of the planning system and were worn down by having to attend lengthy, sterile planning inquiries. In fact, analysis of the responses to the Scottish Executive's survey failed to reveal any basis for this condescending attitude (Poustie 2007) raising wider concerns about the probity of government consultation exercises (Bickerstaff \& Walker 2005). Nevertheless, recognising that for some the opportunity to have their voice heard was an important part of the process, the Scottish Government gave a guarantee that objectors would retain the statutory right to present their case through a public inquiry. However, somewhat confusingly, the same document also proposed that the mode of examination would be determined by the planning reporter.

The White Paper, 'Modernising the Planning System' (Scottish Executive 2005), failed to provide clarification as to what the Scottish Executive's intentions were with regard to LDP public inquiries. Notwithstanding how critical the issue was to the principles of justice and transparency, which the White Paper claimed were priorities, the mode of LDP examination was not discussed in the main text but was instead referred to only briefly in the final appendix. It stated that less reliance would be placed upon public inquiries but that there would be a 'mandatory requirement for a public examination' of a development plan. Although the term 'public examination' was not part of the Scottish planning lexicon it was reasonable to assume that it was intended to be synonymous with the term 'public inquiry'.

After two rounds of public consultation final clarification on the format for scrutinising development plans was only provided through publication of the Planning (Scotland) etc Bill in December 2005. Part 2 , s.19(5) stated that the decision on the format of the examination of the objections was to be at the discretion of the planning Reporter, not the objector. On the face of it, this might have seemed to be a perfectly reasonable alteration with experienced planning Reporters being well placed to judge which form of scrutiny would be most appropriate for resolving specific representations. During questioning by the Scottish Parliament's Local Government \& Communities Committee the Chief Planner stated: "To avoid doubt, I make it clear that the Bill creates a mandatory duty to have a public inquiry on and an examination of strategic development plans" (Mackinnon 2006, clmn. 3358). In regard to local development plan examinations he continued:

"I suspect that a public inquiry is the more appropriate process when the information is uncertain and needs to be explored in more detail...(T)he three options are written representations, an informal hearing and a public inquiry. I suspect that every local plan will go through a mixture of those processes. I suspect we would like more to be dealt with by written submissions and in hearings, but there is no doubt that in some circumstances, a public local inquiry at which evidence is rigorously tested will be appropriate" (author's emphasis in italics, ibid., clmn 3359). 
The Chief Planner's comment, expressed so adamantly, in regard to strategic development plan examinations is virtually incomprehensible given that the Bill specifically did not create any such mandatory duty to hold a public inquiry. Instead, as with LDPs, the Bill left the choice of mode of examination into SDPs to the discretion of the planning Reporter who, under the proposed legislation, would assume an even more pivotal position in the Scottish planning system. Nevertheless, on the basis of the Chief Planner's submission it was not unreasonable for the MSPs on the committee to have concluded that whilst the wording in the Bill left the examination format indeterminate, de facto all top-tier SDPs and all complex issues (such as proposals for new settlements) in lower-tier LDPs would be subject to rigorous scrutiny through a public inquiry. The failure of the committee to have properly appreciated the possible implications of the wording of the Bill vis-à-vis LDP (and SDP) examinations and to challenge the Scottish Government came as a surprise to some civil servants. In an interview with the author, one said:

"A number of us didn't think that clause (withdrawing the right of LDP objectors to a public inquiry) would have a chance before the committee. We thought they'd be all over it immediately given that the proposal hadn't been floated in consultation....we knew that the clause would enormously disadvantage community councils and other objectors. But the view of some (colleagues), bluntly, was that we needed to have a lot less democracy and a lot more development..... We were astonished to get away with it....the committee just didn't do its job."

The extent of the ramifications caused by the failure of the committee to identify and appreciate the implications of the withdrawal of the guaranteed amber light public inquiry protections for local communities is becoming very clear. By November 2016 there had been 4 SDPs and 25 LDPs adopted in Scotland under the auspices of the Planning etc. (Scotland) Act 2006. The four SDP examinations considered, in aggregate, 106 'issues'. None of these issues were subject to a formal or informal hearing; all were considered through written representation. 1776 separate issues were scrutinised in the 25 LDP examinations, with only 23 (1.3\%) being subject to a public inquiry or informal hearing (many of which covered housing land supply). 12 of the LDP examinations were conducted entirely through written representations ${ }^{8}$. To all intents and purposes, as a result of the planning reforms and the 'choices' made by planning Reporters, amber light public inquiries have disappeared from the Scottish planning landscape and very few policies in the SDPs and LDPs have been materially amended following examination under the much lighter touch post-reform procedures.

A planning Reporter suggested that, notwithstanding the wording of the legislation, pressure from Government ministers and their advisers was being applied to minimise the likelihood of a public inquiry being used to evaluate objections into a development plan:

"We have been told, unequivocally, "No public inquiries or hearings into local plans unless it is absolutely unavoidable'. That came from senior civil servants in the government's planning directorate. So the Scottish Government tells councils that they're in charge of the process so long as the local plan has a very generous amount of development land and then tells us (the Reporters) not to interfere. There really are very few checks and balances now on new development, however inappropriate it is".

Quite how this sits with the long established principle of the separation of powers and the right to a fair trial under the European Convention on Human Rights and Fundamental Freedoms is, to put it mildly, open to question. The former Conservative Party spokesman for Housing, Transport and Infrastructure, Alex Johnstone MSP, said:

\footnotetext{
"We have ended up with a very, very, very bad system. But I think that the witnesses were more to blame than the MSPs on the committee. The MSPs were completely misled on the development plan examination issue....they were assured by the Chief Planner that there would be public inquiries into all SDPs and into controversial issues in LDPs. Those assurances have transpired to be $100 \%$ false. Only the lawyers recognised the dangers inherent within the Bill....Labour and now the SNP have surrounded themselves with a cosy cabal of 'Me Too' so-called experts all too keen to give unconditional endorsement to their ill considered planning proposals. Ordinary people have been removed from what is now a near free-for-all system which appears to be council-led but which is really driven by central government with an obsession in meeting absurdly unrealistic development targets. Prohibiting local plan inquiries was nonsense. Fundamental reforms are needed to restore trust in the Scottish planning system...".
} 
These scathing remarks suggest that the reforms were motivated by an overwhelming determination to deliver more development but in a way that gives the appearance that electorally accountable local authorities and neutral planning Reporters are in charge of the process. The repeated references in the White Paper to enhancing citizen involvement were little more than a tempting allurement to seduce unwitting and ill-informed readers into supporting the proposals. Support for the reforms was provided by a former SNP MSP who stated:

"The 2006 reforms have considerably loosened the ties that unnecessarily constrained development. Of course, some community councils and objectors won't be too happy but that is a mark of just how successful the reforms have been. I think that Parliament said in 2006, 'OK, people should be able to have a say in what a development should look like but not in whether or not it should go ahead'. Previously, that was happening far too much in these lengthy inquiries. Now it's mainly behind closed doors and I'm pretty comfortable with that.....we still have some way to go in rolling back the planning system further and making it more developer friendly and that is in hand; but we have more or less neutralised the opportunity for community councillors and objectors to say 'no' so often and that has to be good."

The comments almost perfectly reinforce those of Allmendinger and Haughton (2012) who note, in reference to planning reforms in England, "you can engage in planning at the level of the superficial not the concrete" (ibid., 98).

\section{New settlement planning policy in Scotland}

Planned settlements have a long history in Scotland with around 500 villages having been laid out in the $18^{\text {th }}$ and $19^{\text {th }}$ centuries in line with a master plan drawn up by the landowner (the laird) (Lockhart 1980). During the post-1945 period a series of state-led new towns were built as overspill for the central belt conurbation (East Kilbride; Cumbernauld; Glenrothes; Livingston; and Irvine). Generally, though, the post-1947 planning system has incorporated a longstanding presumption in favour of urban containment which remained in place until the end of the millennium. Strong household growth pressures from the 1980s onward forced the Conservative controlled Scottish Office to explicitly identify the (very limited) circumstances under which a planning authority might entertain a proposal for the creation of a private sector-led new town but, where possible, councils were to make "....full and effective use... of land within existing built-up areas..." (Scottish Office 1993, 5).

But by 2000 , confronted with projections showing further significant increases in the number of households across Scotland, the newly elected Labour-Liberal Democrat coalition sought to develop a less rigid approach to greenfield housing development (National Record of Scotland 2000; Pacione 2004). Moreover, the Scottish Executive was beginning to view the unreformed planning system as a significant contributory factor to Scotland's comparatively poor economic performance (Mackinnon 2001; Lloyd \& Peel 2009). Responding to the concerns of the private sector, new government draft guidance instructed planning authorities to adopt a longer term and more greenfield focused approach to housing land allocation with less reliance upon the contribution from brownfield sites when preparing their development plans (Homes for Scotland 2002; Scottish Executive 2003b).

In April 2007 the Labour/Liberal Democrat coalition was replaced by a minority SNP-led administration. Contending that the previous incumbents had failed to deliver on the widening of the north-south A9 through the Highlands, the construction of the Aberdeen bypass and the Borders railway, the SNP made progress on major infrastructure projects a priority. In October 2007 it launched a discussion document setting out its proposals to tackle the increasing problem of housing affordability in Scotland by increasing output from around 25,000 units per year to 35,000 units by 2015 (+40\%) (Scottish Government 2007). To achieve this objective, planning authorities were advised to release more land in the belief that this would significantly reduce its cost and so bring price rises for housing into line with other goods and services. To place its aspirations in a slightly broader context, the target figure was nearly twice as high as the average output level of 18,600 units per year achieved 1981-1991 (Scottish Government 2018).

Accordingly, the SNP Scottish Government introduced a transformational relaxation of planning policy (Cuthbert \& Cuthbert 2009). The presumption against the development of new settlements 
would only apply where there was a strong supply of identifiable brownfield sites which effectively prevented councils from taking into account the expected yield from unidentified windfall sites (Scottish Government 2008). The need for a more generous supply of housing land was re-emphasised in the new consolidated Scottish planning guidance which stated that development plans should be 'visionary and ambitious' (Scottish Government 2010, 1) and 'aspirational' (ibid., 3).

In 2011 the SNP was returned to government with a majority on a manifesto that included a commitment to '...speed up planning decisions, avoid unnecessary delays in new development and act as a boost for the construction industry' (Scottish National Party 2011, 11). Three years later, it issued new guidance notes advising local authorities to identify a 'housing supply target' which would reflect what could be delivered rather than simply what was needed, with the proviso that the supply should be at least 20\% above projected demand (Scottish Government 2014a, 2014b). The scale of possible delivery would depend upon constraints such as the state of the local construction sector as well as protective designations but this policy change considerably weakened the longstanding link between supply and demand and set the stage for the preparation of planning strategies based more on aspiration than on anticipated levels of demand ${ }^{9}$. Indeed, one might argue that through encouraging a substantial over allocation of land central government policy makers were signalling a move towards the 'sale' of development rights to the applicant offering the greatest level of planning gain (Leunig 2007).

\section{Aberdeen 1973-2008: from new settlements to brownfield development}

Since its discovery in the late 1960s there has been a virtual umbilical link between the production of North Sea oil and proposals for the construction of new settlements around Aberdeen. Indeed, it is quite possible that north-east Scotland was the first area in the UK where a proposal for a private sector-led new settlement was brought forward. The influx of workers into the new industry placed significant pressures on the supply of housing and the existing planning framework anchored by a green belt. In a marked break from the convention of incrementally expanding suburbs a private developer, Christian Salvesen (Properties) Ltd, put forward a pioneering proposal in 1973 for a new town comprising 2,750 houses at Maryculter to the south west of Aberdeen (Fig. 1) (Smith 2000). Although initially supported by Kincardinshire Council, following local government reorganisation the scheme was dropped by the newly created Kincardine \& Deeside District Council and Grampian Regional Council.

The primacy of the local authority-led planning framework in determining the development complexion of the area was evident again when a few years later an alternative new settlement proposal was successfully brought forward by the Ashdale Land and Property Company Ltd, around the village of Westhill located $13 \mathrm{~km}$ west of the city centre beyond the green belt. Other standalone new private housing schemes - which were little more than dormitory suburbs with very few service or employment facilities - such as Kingswells and Balmedie soon followed (Fig. 1).

Grampian Regional Council (GRC) investigated further possibilities for another new settlement but these were abandoned when oil prices collapsed in the mid-1980s (GRC 1986a; Newlands 2000). The structure plan did, however, identify a green belt location at Countesswells, west of the city, as having potential for a new settlement of 1,500 houses (GRC 1986b). With the revival of the North Sea oil sector GRC revisited the possibility of a new settlement as part of the review of the structure plan in 1991. GRC incorporated a proposal for 3,300 houses in an area beyond the green belt south west of the city within the draft structure plan. In the absence of any real likelihood of an amber light public inquiry into the upper tier plan, it was only due to an unexpected and last minute change in the political complexion of the council that the proposal was abandoned (GRC 1992).

Nevertheless, in 1994 a local based house builder decided to submit a planning application for a new settlement at Banchory-Devenick in the area identified in the abandoned plan (Fig. 1). Notwithstanding the planners' contention that the proposal was needed to remedy a housing land supply problem the councillors rejected it. Following an eight week long public inquiry into an appeal, during which a substantial body of evidence of brownfield/windfall housing yields in the Aberdeen Housing Market Area (AHMA) was scrutinised in meticulous detail, the Minister refused the proposal (Scottish Office 1998; Walton 2000). A proposal for another new settlement at nearby Blairs was also 


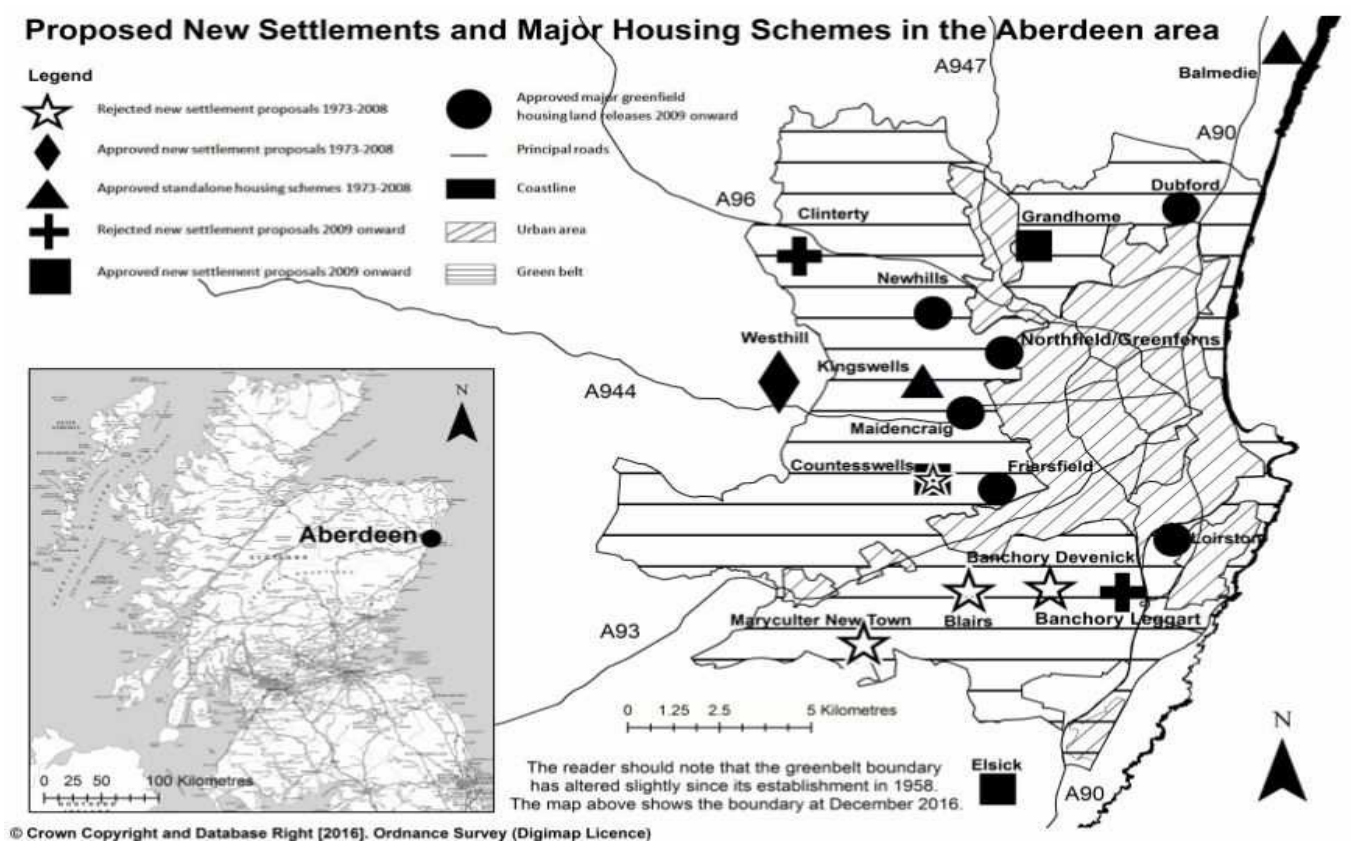

Fig. 1. Major housing development proposals in the Aberdeen area.

refused on appeal - following another public inquiry - due to conflict with green belt policy and a demonstrable supply of brownfield land.

With the Banchory Devenick/Blairs episode settled the replacement structure plan - North East Scotland Together (NEST) approved in 2000 - abandoned a new settlement strategy and focused nearly $80 \%$ of the city's new housing allocation 2000-2010 on brownfield sites. But in the wake of the less restrictive government guidance issued in 2003 Aberdeen City Council issued a draft local plan, Green Spaces: New Places, proposing abandonment of the brownfield focused policy (Aberdeen City Council 2004). Concerned about the lack of family-type housing within the city and the increasingly ageing population profile the council identified seven 'Future New Communities' (FNCs) in the city's green belt for development beyond 2010 including one labelled as a 'new settlement' at Countesswells. Unsurprisingly, the proposals were strongly opposed by the suburban community councils who argued that the FNCs would diminish the green belt. Accordingly, many of the objectors to the plan exercised their statutory amber light right to have their arguments heard at a public inquiry. Confronted with evidence disputing the robustness of the council's long term housing projections and the requirement to release large amounts of land from the city's greenbelt the Reporters found against all of the FNCs. Of note, they found that the new settlement at Countesswells would irreversibly damage the green belt by risking coalescence with neighbouring suburbs (Directorate for Planning and Environmental Appeals 2007a). The outcome left Aberdeen with a housing strategy focused around brownfield development.

\section{Aberdeen 2009 onward: from brownfield development to new settlements}

Shortly after the Scottish Government abandoned its brownfield-first policy and adopted its new panScotland 35,000 homes target, Aberdeen City Council and Aberdeenshire Council set about preparing a joint SDP (Aberdeen City and Shire Strategic Planning Authority 2009). The plan provided 72,000 homes over 24 years (2007-2030), equating to 3,000 units per year (compared to 1,765 units per year in NEST), of which 2,300 per year would be in the AHMA (compared to 1,200 units per year in NEST). 
As output levels in the AHMA 2000-2008 had averaged around 1,625 units per year this apparently significant increased provision actually represented around the $40 \%$ increase required by the Scottish Government to secure affordability. Around 40,000 of these 55,600 AHMA units were to be sourced from greenfield sites - of which around 21,000 would be from within the city's green belt.

Although the newly approved SDP made no provision for a new settlement, several proposals were brought forward by large landowners for inclusion in the two daughter LDPs. Five of the promoted schemes emerged as serious contenders - two in Aberdeenshire (Banchory Leggart and Chapelton of Elsick [Elsick]) - and three in the city (Countesswells, Grandhome and Clinterty) (Fig. 1). Notwithstanding the national guidance policy, neither council considered the absence of provision for new settlements within the SDP as a constraint. Indeed, whilst aware of the risks associated with infrastructure delivery many of the councillors in both authorities considered that a new settlement was a very attractive proposition capable of providing significant wider economic and social benefits and absorbing household growth for decades to come.

Following the process of public consultation and deliberation by the councillors of both authorities the developer bids for projects at Banchory Leggart (3,000 units) and Clinterty (circa 1,500 units) were rejected for inclusion within the respective draft LDPs, primarily on the grounds of the risk of coalescence and conflict with green belt policy in the case of the former and high infrastructure costs in the latter (Aberdeenshire Council 2010; Aberdeen City Council 2010). The new settlement proposal at Elsick, about $15 \mathrm{~km}$ south of the city and beyond the green belt, was promoted through the use of a charette led by the famed new urbanist, Andres Duany (as was Grandhome in Aberdeen) (Elsick Development Company 2011; Macleod 2013) ${ }^{10}$. Like Clinterty, it also required significant new infrastructure provision but, with a capacity of 9,000 units was considered by Aberdeenshire Council as having the potential to become a self-sustaining community (rather than simply a dormitory suburb) and so was included within the draft LDP. In addition to the green belt site at Countesswells (3,000 units), Aberdeen City Council also selected for inclusion within its draft LDP the proposal at Grandhome $(7,000$ units) on the north side of the city which had been one of the FNCs previously rejected by the Reporter in the ill-fated Green Spaces: New Places local plan (Aberdeen City Council 2009).

Each of the three schemes selected by the two authorities was subject to significant levels of objection from neighbouring residents and local community councils. But notwithstanding the inevitable complexity of the issues that arise in the context of a proposal for a new town, government guidance stipulates that written submissions must be concise and not exceed 2,000 words (Scottish Government 2013). None of the three proposed new settlements was subject to a public inquiry and only one (Elsick) was subject to a round table discussion in which the evidence could be expanded. In the context of such a democratic deficit there are risks that some arguments will not be properly explored and potentially superior viable alternatives overlooked (Cornwall 2008).

In each case, adopting a light touch approach, the presiding Reporter neatly side stepped making any finding on the compatibility of the proposal with national guidance or the SDP and held that each proposal should be incorporated into the new LDP. Unlike his predecessor presiding over Green Spaces: New Places, the Reporter made no finding on the possibility of Countesswells coalescing with surrounding suburbs notwithstanding that it was double the size of the earlier rejected scheme (Directorate of Planning and Environmental Appeals 2011a). One community councillor interviewee said:

"We knew that the developers were going to grab some of the green belt. They have been trying to release land at Countesswells for decades....and now another new town....But we said that the development should be much smaller than 3,000 houses....about 1,500 houses with the rest going to Clinterty. We would have liked a public inquiry.....we could have put our argument thoroughly and challenged the council and the developer....We made comments to the plan but in truth that's just a waste of time....we're asked what we think about it but at the same time we're denied an effective forum to say what we think. How just is that? The 2006 Act effectively destroyed the planning system in Scotland....it's now just a developer's charter."

A community councillor from a neighbouring area expressed similar sentiments:

"More or less the same project (Countesswells) was put forward some years ago in Green Spaces: 
New Places. Then there was an inquiry. The community council gave evidence against the new town. It was right in the middle of the green belt. We said the scheme would cause Cults to merge with Kingswells....we went into great detail in our evidence....Yes, there was cross examination but that wasn't a concern.....we objected this time around but what can you say in just 2,000 words?.... the 2006 Act is in need of a complete overhaul.....it's a disgrace.....yes, we will participate again but I doubt it would have much effect."

On Grandhome the Reporter held that the risk that the Scottish Government might not provide the funds necessary for strategic transport infrastructure improvements did not warrant removing it from the plan. Once again, a local community councillor expressed dismay at the process:

"We'd made representations about the Grandhome development in the local plan.....the developers had held a charrette to get the community's input....these are highly manipulative exercises (cf. MacCleod 2013)....we were not allowed to question the principle of the development....most opposed the project but the developer produced a fancy document claiming the very opposite..... we thought that it was just far too much development for the area's road network..... I was told that there would be an LDP inquiry....we submitted short written comments....later we found out that the Reporters had already approved the scheme....it's as if the community voice no longer matters.... if the rules aren't changed then you have to ask yourself what is the point of making representations since they seem to be just ignored."

Finally, on Elsick, whilst the Reporter noted that there were risks of under delivery caused by high infrastructure costs he concluded that these could be offset if necessary by bringing forward development on other sites (Directorate for Planning and Environmental Appeals 2012a). An unimpressed community councillor commented:

"We heard there was going to be one of these charrettes for Elsick run by some American chap called Duany....national planning guidance stated that a new settlement could only be brought forward in the LDP where it was in the SDP - and it wasn't. So we were more than a little surprised when the Chief Planner from the Scottish Government turned up to a public meeting to heap praise on the process by which the scheme was being promoted ${ }^{11}$....these charrettes just bypass normal planning procedures (cf. MacCleod 2013).....the hearing was also a farce....one of the main parties didn't even turn up....you couldn't question the applicant or council directly.....when the Reporter was asked why there wasn't a proper inquiry he responded 'well, you've had a charrette'.... the Reporter was not interested about compliance with the strategic plan or national guidance.... the statutory planning framework appears to be an irrelevance....at a public inquiry a barrister would have torn the council's case to shreds....just like the objectors did at the Banchory-Devenick public inquiry....but that can't happen at these wishy-washy, let's have a chat informal hearings.... it's now such a dumbed-down process - pithy written submissions, brief meaningless chats....the abolition of public inquiries has been a disaster for Scottish communities, for Scottish planning and for Scottish democracy.....yes, we'd respond again I suppose but not with any great expectations....I watched many of the planning Bill committee hearings.... why on earth did they agree to extend a completely ineffective system for scrutinising structure plans to local plans?.....it beggars belief.... the debate was dismal....this is planning's own 'Dangerous Dogs Act'12....public inquiries for development plan proposals above a certain size threshold should be mandatory."

Notwithstanding the very limited size of the survey, what is clear from the consistent and forceful testimony of the community councillors is that - contrary to earlier claims made by the Scottish Executive - there is no apparent support for the removal of the automatic right to a public inquiry or any apparent fear of appearing before such a forum. Instead, there is a deep frustration and sense of anger that they, as members of a statutory body, have been denied the opportunity to challenge what might be a cosy council/developer consensus and properly test the council's case due to an ill considered change in the law. Moreover, these responses appear to be symptomatic of more widely held views concerning a loss of trust in the Scottish planning system as suggested by Alex Johnstone MSP. Three reports have affirmed this view with the National Trust for Scotland finding that $60 \%$ of the Scottish population believe that they have 'no' influence at all in affecting planning decisions and another 27\% stating that they have 'very little' influence (Beveridge et al. 2016; National Trust for Scotland 2017; Yellow Book Ltd 2017). As Allmendinger and Haughton $(2012,98)$ note in their analysis of post politics planning; "At worst, planners were complicit in this deceit (circumventing the political), helping alienate the profession from the communities they formerly represented". 


\section{Is north-east Scotland poised for an oil-led property crash?}

The planned new settlements at Elsick, Grandhome and Countesswells are just three components within an expansive greenfield-led housing strategy devised for north-east Scotland (Aberdeen City and Shire Strategic Planning Authority 2014). Aberdeen City Council has identified 'masterplan zones' in its LDP for 550 units at Dubford, 3,000 units at Newhills, 2,800 units at Northfield/Greenfearns, 750 units at Maidencraig, 550 units at Friarsfield and 1,500 units at Loch Loirston (Fig. 1). Underpinning this strategy was the assumption that the offshore oil sector would continue to thrive. However, the ink on the new SDP had barely dried when, due to an international glut brought about by fracking in the USA and an increase in output by Saudi Arabia, oil prices collapsed from around $\$ 110$ per barrel in June 2014 to just $\$ 31$ by January 2016. Contraction of North Sea oil production has led to the direct loss of around 160,000 jobs in the UK since 2014, with the number claiming unemployment benefit increasing in Aberdeen and Aberdeenshire by 69\% and 92\% respectively 2015-2016 (Scottish Parliament 2016; Oil and Gas UK 2017). House prices have fallen further in Aberdeen than in any other local authority in the UK 2015-2016 (The Press and Journal 2016a). The future for the North Sea is likely to be one of declining levels of oil production, increased efficiency, falling employment levels and increased expenditure on platform decommissioning.

Implicitly, the question arises as to whether there is a real prospect of a property crash in north-east Scotland through over production of housing? Within the AHMA developers are being invited to deliver around 2,300 units per year 2015-2030, during what might be a protracted and possibly irreversible economic decline, compared to a historically high take-up rate of around 1,500 units per year 2000-2014 when the local economy was generally buoyant (Aberdeen City Council \& Aberdeenshire Council 2005, 2010, 2016). Moreover, whereas previously a very large part of the output had been sourced from small brownfield sites with relatively modest infrastructure costs, the large greenfield allocations in the current local plans, and in particular the new settlements, will have high advanced costs due to high planning gain obligations and thus higher commercial risks.

Although it is too early to answer the above question definitively there are factors which suggest that the spectre of half built estates in north-east Scotland - and beyond ${ }^{13}$ - is a distinct possibility. Notwithstanding the oil crisis, most of the developers of large greenfield sites in the city have progressed their proposals through the masterplan stage to planning permission. Construction has started at Elsick and Countesswells. Initially the developer at Elsick envisaged output of around 250 units per year implying completion of phase-one (4,000 units) within about 16 years (Aberdeenshire Council 2010). But four years after full planning permission was granted for the first section of the new urbanism project, just 102 houses have been sold or reserved (Elsick Development Company 2017). At Countesswells, the developer has announced that the first new homes will soon be ready for purchase in what will eventually be a garden community in harmony with nature (The Press and Journal 2016b). Construction of new access roads has commenced for the new community at Grandhome which the developers say will embody the architectural heritage of the medieval precinct of Old Aberdeen (Grandhome Trust 2013).

The rush by landowners to bring these sites forward despite such dire economic circumstances is a reminder of the inherent lack of collective logic within so-called organised capitalism (Offe 1985). Landowners and developers inevitably argue for their sites to be released for development during plan reviews in order to enhance their capital value, whilst also opposing land releases elsewhere to protect that enhancement. Once a site has been approved developers will be confronted with a form of prisoner's dilemma as they try to second guess the actions of competitors and calculate the commercial risks between proceeding and not proceeding with the project, with the degree of certainty being broadly in inverse proportion to the number of competitor sites (Adams \& Watkins 2014). There is a perceived inherent contradiction between what is good for the one and what is good for the collective whole, suggesting that tight land use planning regulation is a prerequisite for, rather than a threat to, the successful accumulation of land development capital (Dear \& Scott 1981). In Aberdeen, even the option of the imposition of a variant of a phasing condition - permitting only one new settlement to be brought forward at a time - has been overlooked. The protective framework 
that once provided certainty to developers and communities has largely been removed in Scotland through the deregulation of the planning system.

\section{Conclusions}

Planning policy in north-east Scotland in regard to the provision of private new settlements has moved almost full circle since commencement of construction of Westhill in the 1970s was followed by a succession of rejections for similar proposals during the 1990s and 2000s, through to their reemergence as a preferred form of development following the planning reforms introduced from 2006 onward. What is significant is that during the period of constraint the three principal parties within the planning system - developers/landowners, the public and the local state - were each able to exert their influence on one another within a system that permitted dissenting voices through the use of amber light checks and balances.

This state of affairs was, however, completely changed following the introduction of the Planning etc (Scotland) Act 2006 through which automatic amber light checks on the new generation of 'ambitious' and 'aspirational' development plans were removed. As Allmendinger and Haughton $(2012,90)$ note:

"...there is a danger that the resulting planning system is not so much an empowering arena for debating wide-ranging societal options for future development, as a system focussed on carefully stage-managed processes with subtly but carefully defined parameters of what is open for debate. The system gives the superficial appearance of engagement and legitimacy whilst focusing on delivering growth expedited through some carefully choreographed processes for participation which minimise the potential for those with conflicting views to be given a meaningful hearing."

The reform proposals set out in the White Paper were superficially attractive and thus potentially appealing to MSPs and many of the parliamentary committee witnesses with little more than a skindeep knowledge and understanding of the planning system. The White Paper spoke about the need for greater public engagement, but these statements were firmly within the context of achieving economic growth. A careful reading of the proposals would have revealed the Scottish Government's ambivalence and near hostility to local plan inquiries and the obvious implications this would have for meaningful participation. Nevertheless, only a small handful of the witnesses identified probably the most anti-democratic measure introduced into any planning system in the UK, removing the right established in the early 1970s to have a development plan objection heard at a public hearing ${ }^{14}$. It is difficult to recall a time when 35 years' worth of hard-won community rights were so casually jettisoned by Parliament and those advising it. The failure of the Parliament to recognise the potential consequences of the changes is symptomatic of the dangers of a non-vigilant (and an ill-informed) legislature and a reminder of the critical role played by the courts as a backstop against the misuse of government power.

The evidence available so far suggests that the de facto removal of LDP-public inquiries is perhaps more consistent with a form of post-politics stage-management aimed at securing economic growth, as argued by Allmendinger and Haughton (2012), than with Harlow and Rawlings' (2009) green light approach seeking to advance wider collective interests, although further research in the politics surrounding development plan adoption across Scotland is required. What we can say is that from its inception, the planning reform project appears to have been motivated by a deep-seated desire of Ministers and senior civil servants to lull Parliament into heavily diluting longstanding community procedural safeguards in the belief that this would facilitate increased levels of development. Planning reform has produced administrative efficiencies but at the marked expense of individual and community rights and amber light scrutiny (Pacione 2014) ${ }^{15}$. Or put another way, the need for outputbased legitimacy, described as the "...speedy provision of urban space, new dwellings and more jobs..." (Falleth et al. 2010, 748), has subjugated the need for input-based legitimacy (the right of the public to shape plans). Paradoxically, however, the reforms have failed to deliver increased output due to changed economic circumstances. Annual housing completions for Scotland have not exceeded 17,600 units post-2009, barely half of the Scottish Government's target of 35,000 units per year by 2015 (Scottish Government 2017a). 
Perhaps because of these shortcomings the Scottish Government is now intent on diluting further those protections the public have been allowed to cling on to in order to speed up development delivery. Following consultation in 2016 on 'root and branch' reforms the Scottish Government has indicated that it is minded to introduce an even lighter form of development plan scrutiny with a draft being 'gatechecked' at an early stage in the process by a Reporter to ensure that the technical evidence base is sufficiently robust and to obviate any need for detailed examination later on. Under this streamlined system it is inevitable that there will be even fewer oral hearings, with the only real recourse for the public being through the use of judicial review ${ }^{16}$. Further, once a site has been allocated for development the Scottish Government is proposing that there should be less opportunity for commenting on, and objecting to, any subsequent planning application (Scottish Government 2017b).

Such a deregulatory approach, whilst intended as a market stimulus, is highly vulnerable to the vicissitudes of the local economy, as demonstrated by the case study of Aberdeen. With the collapse of international oil prices the policy of seeking to allocate so much greenfield land for development around the city now seems very ill judged. It is a little ironic that the concept of the new settlement, which was first brought forward largely in response to the housing pressures generated by the exploitation of North Sea oil, was rejected in virtually all cases only to be embraced some 35 years or so later just when that same resource base appears to have entered a spiral of irreversible decline.

Advocates of planning liberalisation would argue that an increased land supply will result in greater housing affordability and the satisfaction of previously suppressed demand. However, in Aberdeen and elsewhere the policy has been applied uncritically to the point where many communities appear to have lost trust in the planning system. This trust will be restored only once the public are again allowed to voice genuine dissent in a meaningful 'amber light' public forum since this will help ensure that the decisions of planning authorities and Reporters are made with greater rigor and are more likely to reflect a wider set of concerns. To this effect, it is suggested that automatic public inquiry rights ought to be reinstated to all local plan objectors. And whilst there is certainly no suggestion here that all new settlement proposals are doomed to failure there is a real prospect that some or all of the ambitious development proposals in the north-east so alluringly depicted by the developers will end up as abandoned building sites, and a source of considerable embarrassment to a government committed to creating desirable sustainable communities.

\section{Notes}

${ }^{1}$ A community council is a statutory body constituted to represent the views of the citizens of an urban neighbourhood, suburb or rural area to its parent local authority on a range of local issues, including planning. Most community councillors volunteer themselves for duty and are unelected.

2 Some academics have questioned the validity and usefulness of post-politics as an over-arching theory. Whilst acknowledging that the concept should not be abandoned, Metzger (2018) contends that there is a need for greater clarity as to what post-politics really is, greater specification to distinguish it from other forms of de-politicising practices and, ultimately, greater opposition from those whom are marginalised by its debilitating effects.

${ }^{3}$ Prior to 1999 Scotland was governed from Edinburgh by the Scottish Office, a UK-Government department. Following devolution Scotland was run by an administration known as the Scottish Executive until 2007 when the new Scottish National Party minority administration unilaterally rebadged it as the Scottish Government. This renaming was formalised under s.12(1) Scotland Act 2012.

${ }^{4}$ SDPs and LDPs are the new labels given under the Planning etc (Scotland) Act 2006 for what were previously known as structure plans and local plans respectively.

${ }^{5}$ A planning Reporter is a government civil servant whom is empowered under statute to adjudicate (or make a recommendation to the Minister) on a range of planning disputes including appeals against refusal of planning permission and on examinations into development plans. In their role as de facto judges, they are supposed to be at arms length from the Scottish Government so as to meet the requirements of the right to a fair trial guaranteed by Article 6 of the European Convention on Human Rights. 
${ }^{6}$ In England and Wales the success rate for parties contesting the total of 10,000 or so planning appeals considered each year 2010-2017 through written representations, hearings and public inquiries has been between $30-33 \%, 40-47 \%$ and $49-63 \%$ respectively (UK Government 2018). In Scotland, the overall success rate for the 300 or so appeals considered each year since 2010 has been around $40-45 \%$ with the rate for written representations sometimes being higher than that for public inquiries (Directorate for Planning and Environmental Appeals 2010, 2011b, 2012b, 2013, 2014, 2015). However, there are only around 10-20 public inquiries held each year in Scotland (compared to over 300 in England and Wales).

7 For example, the inquiry into the Aberdeen City Local Plan 'Green Spaces; New Places' ran from January 2007 to December 2007, consuming 409 Reporter-days. The West Lothian, East Lothian, Scottish Borders and Angus local plan inquiries consumed 306, 158, 226 and 117 Reporter-days respectively during 2006/2007 (Directorate for Planning and Environmental Appeals 2007b).

${ }^{8}$ Data provided by the Directorate for Planning and Environmental Appeals to the author under a Freedom of Information request.

${ }^{9}$ It is possible that the Scottish Government, as part of a policy of seeking to increase the national population, wishes to drive down housing prices to induce demand from those living outside Scotland. ${ }^{10} \mathrm{~A}$ charette is the name given to an intensive consultation exercise, usually taking the form of a workshop and lasting several days, during which members of the public inform the drafting of a masterplan for a major new development such as a new town.

${ }^{11}$ There was a call by some MSPs for an investigation into the role of the Chief Planner in six Andres Duany charette-led development schemes (The Times 2011).

12 The Dangerous Dogs Act 1991 was introduced in response to a number of fatal attacks by dogs on young children. It was widely criticised for being ill-thought out and is frequently cited as shorthand for poorly drafted legislation.

${ }^{13}$ A similar greenfield expansionist scenario has played out in Perth (part of the Dundee city-region) in central Scotland where, despite the failure of a developer to deliver any houses at a new settlement (Oudenarde) approved in 2006, a new LDP was adopted in 2014 without public examination providing for a further three new settlements at Almond Valley (1,500 units), Perth West (550 units) and Bertha Park (3,000 units).

${ }^{14}$ See s.9(3)(b) and s.13(1) of the Town and Country Planning Act 1971 regarding objections to structure plans and local plans respectively.

15 In 2009 a grassroots, community organisation called Planning Democracy was formed to challenge the dilution of community rights in the planning process across Scotland (The Sunday Herald 2009). Surprisingly, it did not make specific reference in its 'manifesto' to the de facto withdrawal of LDP inquiries (Planning Democracy 2012).

${ }^{16}$ Notwithstanding the deregulatory changes to the Scottish planning system, the right to challenge a decision on a point of law through 'red light' judicial review remains (although the former First Minister, Alex Salmond, unsuccessfully called for the right to be withdrawn in certain circumstances (The Herald 2011)). Judicial challenges are financially highly risky although litigants may gain significant cost protection under the Convention on Access to Information, Public Participation in Decision-Making and Access to Justice in Environmental Matters signed at Aarhus in 1998.

\section{Acknowledgments}

I am very grateful to Ms Emily Forster, former geography student at Northumbria University, for the production of Figure 1.

\section{References}

Aberdeen City Council \& Aberdeenshire Council (2005) Housing Land Audit 2005. Aberdeen City Council, Aberdeen.

Aberdeen City Council \& Aberdeenshire Council (2010) Housing Land Audit 2010. Aberdeen City Council, Aberdeen. 
Aberdeen City Council \& Aberdeenshire Council (2016) Housing Land Audit 2016. Aberdeen City Council, Aberdeen.

Aberdeen City and Shire Strategic Planning Authority (2009) Aberdeen City and Shire Structure Plan. Aberdeen City and Shire Strategic Planning Authority, Aberdeen.

Aberdeen City and Shire Strategic Planning Authority (2014) Aberdeen City and Shire Strategic Development Plan 2014. Strategic Development Plan Authority, Aberdeen.

Aberdeen City Council (2004) Green Spaces: New Places. The Finalised Aberdeen Local Plan. Aberdeen City Council, Aberdeen.

Aberdeen City Council (2009) Aberdeen Local Development Plan: Main Issues Report. Aberdeen City Council, Aberdeen.

Aberdeen City Council (2010) Enterprise, Strategic Planning and Infrastructure Committee, 31st May 2010. Aberdeen Local Development Plan - Main Issues Report Consultation Responses - EPI/10/150. Aberdeen City Council, Aberdeen <http://committees.aberdeencity.gov.uk/ieListDocuments. aspx?Cld=140\&M/d=1560\&Ver=4>. 12.08.2017.

Aberdeenshire Council (2010) Report to the Kincardine and Mearns Area Committee, 26 ${ }^{\text {th }}$ January. Aberdeenshire Local Development Plan. Main Issues Report. Issues and Responses Volume 2. Settlement Strategy Issues. Aberdeenshire Council, Stonehaven.

Adams, D. \& Watkins, C. (2014) The Value of Planning. RTPI Research Report No. 5. Royal Town Planning Institute, London.

Allmendinger, P. \& Haughton, G. (2012) Post-political spatial planning in England: a crisis of consensus? Transactions of the Institute of British Geographers 37(1) 89-103. https://doi.org/10.1111/j.1475-5661.2011.00468.x

Barker, K. (2004) Review of Housing Supply. Delivering Stability: Securing Our Future Housing Needs. Final Report - Recommendations. H M Stationery Office, London.

Beveridge, C., Biberbach, P. \& Hamilton, J. (2016) Empowering Planning to Deliver Great Places: An Independent Review of the Scottish Planning System. Scottish Government, Edinburgh.

Bickerstaff, K. \& Walker, G. (2005) Shared visions, unholy alliances; power, governance and deliberative processes in local transport planning. Urban Studies 42(12) 2123-2144. https://doi.org/10.1080/00420980500332098

Cornwall, A. (2008) Unpacking participation: models, meanings and practices. Community Development Journal 43(3) 269-283. https://doi.org/10.1093/cdj/bsn010

Counsell, D., Haughton, G. \& Allmendinger, P. (2012) Growth management in Cork through boom, bubble and bust. European Planning Studies 22(1) 46-63. https://doi.org/10.1080/09654313.2012.722975

Cullingworth, B. \& Nadin, V. (2002) Town and Country Planning in the U.K. 12 ${ }^{\text {th }}$ ed. Routledge, London.

Cuthbert, J. \& Cuthbert, M. (2009) SNP economic strategy: neo-liberalism with a heart. In Hassan, G. (ed.) The Modern SNP: From Protest to Power, 105-119. Edinburgh University Jim Press, Edinburgh. https://doi.org/10.3366/edinburgh/9780748639908.003.0009

Davies, K. C. (1969) Discretionary Justice: A Preliminary Inquiry. University of Illinois Press, Urbana.

Dear, M. \& Scott, A. (1981) Urbanisation and Urban Planning in a Capitalist Society. Methuen, London.

Deas, I. (2014) The search for territorial fixes in subnational governance: city-regions and the disputed emergence of post-political consensus in Manchester, England. Urban Studies 5(11) 2285-2314. https://doi.org/10.1177/0042098013510956

Dicey, A. V. (1902) The Law of the Constitution. MacMillan and Co Limited, London.

Directorate for Planning and Environmental Appeals (2007a) Report into objections to Aberdeen Local Plan. DPEA, Falkirk. <http://www.aberdeencity.gov.uk/nmsruntime/saveasdialog. asp? $\| D=10974 \& s / D=7762>04.08 .2017$.

Directorate for Planning and Environmental Appeals (2007b) Review of the Year 2006-2007. Scottish Executive, Edinburgh.

Directorate for Planning and Environmental Appeals (2010) Scottish Government Planning and Environmental Appeals Annual Review. <http://Www.gov.scot/Topics/Built-Environment/planning/ Appeals/ourperformance/annualreviews>. 20.02.2018.

Directorate for Planning and Environmental Appeals (2011a) Report to Aberdeen City Council. Local Development Plan Examination. Aberdeen City Local Development Plan. 22nd December 2011. DPEA, Falkirk. <http://www.dpea.scotland.gov.uk/CaseDetails.aspx?id=95373>. 04.08.2017.

Directorate for Planning and Environmental Appeals (2011b) Scottish Government Planning and Environmental Appeals Annual Review. <http://www.gov.scot/Topics/Built-Environment/planning/ Appeals/ourperformance/annualreviews>. 20.02.2018. 
Directorate for Planning and Environmental Appeals (2012a) Report to Aberdeenshire Council. Local Development Plan Examination. Aberdeenshire Local Development Plan. 9 ${ }^{\text {th }}$ March 2012. DPEA, Falkirk. <http://www.dpea.scotland.gov.uk/CaseDetails.aspx?id=105305>. 04.08.2017.

Directorate for Planning and Environmental Appeals (2012b) Scottish Government Planning and Environmental Appeals Annual Review. <http://www.gov.scot/Topics/Built-Environment/planning/ Appeals/ourperformance/annualreviews >. 20.02.2018.

Directorate for Planning and Environmental Appeals (2013) Scottish Government Planning and Environmental Appeals Annual Review. <http://www.gov.scot/Topics/Built-Environment/planning/ Appeals/ourperformance/annualreviews>. 20.02.2018.

Directorate for Planning and Environmental Appeals (2014) Scottish Government Planning and Environmental Appeals Annual Review. <http://www.gov.scot/Topics/Built-Environment/planning/ Appeals/ourperformance/annualreviews $>$. 20.02.2018.

Directorate for Planning and Environmental Appeals (2015) Scottish Government Planning

and Environmental Appeals Annual Review. <http://www.gov.scot/Topics/Built-Environment/planning/ Appeals/ourperformance/annualreviews >. 20.02.2018.

Elsick Development Company (2011) Chapelton of Elsick: Post-Charrette Paper. Elsick Estate Office, Aberdeen.<http://chapeltonofelsick.com/wp-content/uploads/2012/10/LargeFiles/ ChapeltonPostCharrettePaperFebruary2011.pdf>. 17.07.2017.

Elsick Development Company (2017) News update. <http://chapeltonofelsick.com/news/>. 03.11.2016.

Falleth, E., Hanssen, G. \& Saglie, I. (2010) Challenges to democracy in market-oriented urban planning in Norway. European Planning Studies 18(5) 737-752. https://doi.org/10.1080/09654311003607729 Ganz, G. (1972) "Allocation of decision-making functions". Public Law 215, 216.

GRC (1986a) Grampian Region (Part) Structure Plan: Aberdeen Area Review. Technical Report: 3 - New Settlement - Alternative Locations and Implementation Issues. GRC, Aberdeen.

GRC (1986b) Grampian Region (Part) Structure Plan: Aberdeen Area Review - Written Statement. GRC, Aberdeen.

GRC (1992) Grampian Structure Plan. Consultative Draft. GRC, Aberdeen.

Grandhome Trust (2013) Grandhome Development Framework. Aberdeen City Council, Aberdeen. <http://www.aberdeencity.gov.uk/nmsruntime/saveasdialog.asp?/ID=53124\&s/D=23995>. 22.11.2016.

Harlow, C. \& Rawlings, R. (2009) Law and Administration. Cambridge Press, Cambridge. https://doi. org/10.1017/CBO9780511809941

Haughton, G., Allmendinger, P. \& Oosterlynck, S. (2013) Spaces of neoliberal experimentation: soft spaces, postpolitics and neoliberal governmentality. Environment and Planning A 45 217-234. https://doi.org/10.1068/a45121

Homes for Scotland (2002) Response to Consultation Drafts: NPPG3 Planning for Housing and PAN 38 Housing Land. Homes for Scotland, Edinburgh. <http://webcache.googleusercontent.com/ search?q=cache:Oi42XZqogKMI:www.homesforscotland.com/Portals/HomesForScotland/Documents/ Text__Final_Submission_to_Scottish_Executive.doc+\&cd=3\&hl=en\&ct=clnk\&gl=fi>. .

Leunig, T. (2007) In My Back Yard: Unlocking the Planning System. CentreForum, London.

Lloyd, M. \& Peel, D. (2009) New labour and the planning system in Scotland: an overview of a decade. Planning, Practice and Research 24(1) 103-118. https://doi.org/10.1080/02697450902742197

Lockhart, D. (1980) Scottish village plans: a preliminary analysis. Scottish Geographical Magazine 96(3) 141-157. https://doi.org/10.1080/00369228008736468

MacCleod, G. (2013) New urbanism/smart growth in the Scottish Highlands: mobile policies and post-politics in local development planning. Urban Studies 50(11) 2196-2221.

https://doi.org/10.1177/0042098013491164

Mackinnon, J. (2001) Oral evidence of Chief Planner to the Transport and Environment Committee, $12^{\text {th }}$ September 2001. Scottish Parliament, Edinburgh.

Mackinnon, J. (2006) Oral Evidence to the Scottish Parliament Communities Committee, Planning etc (Scotland) Bill 20015. Stage 1. Scottish Parliament, Edinburgh.

Megarry, R. (1944) Administrative quasi-legislation. 60 Law Quarterly Review 125.

Metzger, J. (2018) 'Postpolitics and planning'. In Gunder M., Madanipouri, A. \& Watson, V. (eds.) The Routledge Handbook of Planning Theory, 180-193. Routledge, Abingdon.

National Record of Scotland (2000) 1998-Based Household Projections for Scotland. Scottish Government Statistical Bulletin Housing Series: HSG/2000/4. <http://www.gro-scotland.gov.uk/ statistics-and-data/statistics/statistics-by-theme/housholds/household-projections/archive/1998based-household-projections>. 13.08.2017. 
National Trust for Scotland (2017) Planning for Scotland - Citizen Views. Heritage Observatory Briefing Note, November 2017. National Trust for Scotland, Edinburgh.

Newlands, D. (2000) The oil economy. In Fraser, W. H. \& Lee, C. (eds.) Aberdeen 1800-2000: A New History, 126-152. Tuckwell Press, East Linton.

Offe, C. (1985) Disorganized Capitalism: Contemporary Transformations of Work and Politics. Polity Press, Cambridge.

Oil \& Gas UK (2017) Economic Report 2017. Oil \& Gas UK, London.

Oosterlynck, S. \& Swyngedouw, E. (2010) Noise reduction: the postpolitical quandary of night flights at Brussels airport. Environment and Planning A 42 1577-1594. https://doi.org/10.1068/a42269

Owens, S. \& Cowell, R. (2011) Land and Limits: Interpreting Sustainability in the Planning Process. Routledge, London.

Pacione, M. (2004) Household growth, housing demand and new settlements in Scotland. European Planning Studies 12(4) 517-535. https://doi.org/10.1080/0965431042000212768

Pacione, M. (2014) The power of public participation in local planning in Scotland: the case of conflict over residential development in the metropolitan green belt. GeoJournal 79 31-57. https://doi.org/10.1007/s10708-013-9477-y

Peel, D. \& Lloyd, M. (2006) The twisting paths to planning reform in Scotland. International Planning Studies 11(2) 89-107. https://doi.org/10.1080/13563470601027730

Peel, D. \& Lloyd, M. (2007) Neo-traditional planning: towards a new ethos for land use planning? Land Use Policy 24 396-403. https://doi.org/10.1016/j.landusepol.2006.05.003

Planning Democracy (2012) People, Power and Planning: The Planning Democracy Manifesto. <http:// www.planningdemocracy.org.uk/resources/PAP summary finalweb.pdf>. 22.11.2017.

Poustie, M. (2007) Planning reforms in Scotland. Journal of Planning \& Environment Law 2007(7) 489-517.

Rydin, Y. (1993) The British Planning System: An Introduction. Macmillan, Basingstoke. https://doi.org/10.1007/978-1-349-22823-2

Scottish Executive (2003a) Modernising Public Local Inquiries: A Consultation Paper. Scottish Executive, Edinburgh.

Scottish Executive (2003b) National Planning Policy Guideline No. 3. Planning for Housing. Scottish Executive Development Department, Edinburgh.

Scottish Executive (2005) White Paper: Modernising the Planning System. HM Stationery Office, Edinburgh.

Scottish Government (2007) Firm Foundations: The Future of Housing in Scotland - A Discussion Document. Scottish Government, Edinburgh.

Scottish Government (2008) Scottish Planning Policy No. 3. Planning for Homes. Scottish Government, Edinburgh.

Scottish Government (2010) Scottish Planning Policy. Scottish Government, Edinburgh.

Scottish Government (2013) Development Planning. Circular 6/2013. Scottish Government, Edinburgh.

Scottish Government (2014a) Housing Needs and Demand Assessment. A Manager's Guide 2014. Scottish Government, Edinburgh.

Scottish Government (2014b) Scottish Planning Policy. Scottish Government, Edinburgh.

Scottish Government (2017a) Housing Statistics for Scotland - New Build Summary. Scottish Government, Edinburgh. <http://www.gov.scot/Topics/Statistics/Browse/Housing-Regeneration/ HSfS/NewBuild>. 01.09.2017.

Scottish Government (2017b) Places, People and Planning: A Consultation on the Future of the Scottish Planning System. Scottish Government, Edinburgh.

Scottish Government (2018) Housing Statistics for Scotland - New Build Summary. Scottish Government, Edinburgh.<http://www.gov.scot/Topics/Statistics/Browse/Housing-Regeneration/HSfS/ NewBuildSummary>.

Scottish National Party (2011) Scottish National Party Manifesto 2011: Re-elect a Scottish Government Working For Scotland. SNP, Edinburgh.

Scottish Office (1993) National Planning Policy Guideline No. 3 Land for Housing. Scottish Office, Edinburgh.

Scottish Office (1998) Report of Re-Opened Public Inquiry into Proposed New Settlement at Banchory Devenick, Aberdeenshire. P/PPA/GD/483 Inquiry Reporters Unit, Falkirk.

Scottish Parliament (2016) Financial Scrutiny Unit Note: Aberdeen and Aberdeenshire since the Oil Price Fall. SPICe Briefing 16/20. Scottish Parliament, Edinburgh.

Short, J., Fleming, S. \& Witt, S. (1986) Housebuilding, Planning and Community Action: The Production and Negotiation of the Built Environment. Routledge, London. 
Smith, A., Williams, G. \& Houlder, M. (1986) Community influence on local planning policy. Progress in Planning 25 1-82. https://doi.org/10.1016/0305-9006(86)90001-2

Smith, J. (2000) Villages and suburbs. In Fraser, W. \& Lee, C. (eds.) Aberdeen 1800-2000: A New History, 466-489. Tuckwell Press, East Linton.

Sossin, L. \& Smith, C. (2003) Hard choices and soft law: ethical codes, policy guidelines and the role of the courts in regulating government. 40 Alberta Law Review 871.

The Herald (2011) Salmond hits out as by-pass objector files new legal bid. Glasgow, 14.09.2011 $<$ http://www.heraldscotland.com/news/13036386. Salmond hits out as bypass objector files new legal bid/>. 19.04.2018.

The Sunday Herald (2009) Citizens unite to battle fast-tracked 'dirty' developments, Glasgow 11.07.2009.

The Times (2011) Call for inquiry into links between US architect and planning chief. London, 08.10.2011. <https://www.thetimes.co.uk/article/call-for-inquiry-into-links-between-us-architect-andplanning-chief-p5grstbkzvb>. 19.04.2018

The Press and Journal (2016a) Worst price falls in UK as oil downturn hits property hard 19.10.2016

The Press and Journal (2016b) Countesswells - A new place with nature at its heart, Your Home supplement 16.11.2016 <https://Www.pressandjournal.co.uk/fp/lifestyle/home/1085889/ countesswells-nature-heart/>. 19.04.2018.

Tyme, J. (1978) Motorways versus Democracy. Macmillan, London. https://doi.org/10.1007/978-1-349-15920-8

UK Government (2018) Official Statistics: Planning Inspectorate Statistics. <https://www.gov.uk/ government/statistics/planning-inspectorate-statistics> 20.01.2018.

Wade, H. \& Forsyth, C. (2000) Administrative Law. $8^{\text {th }}$ ed. Oxford Press, Oxford.

Walton, W. (2000) Windfall sites for housing: an underestimated resource. Urban Studies 37(2) $391-$ 408. https://doi.org/10.1080/0042098002249

Webster \& Lavers (1991) The effectiveness of public local inquiries as a vehicle for public participation in the plan making process: a case study of the Barnet unitary development plan inquiry. Journal of Planning and Environment Law 1991 803-813.

Yellow Book Ltd (2017) Barriers to Community Engagement in Planning: A Research Study. Scottish Government, Edinburgh. 